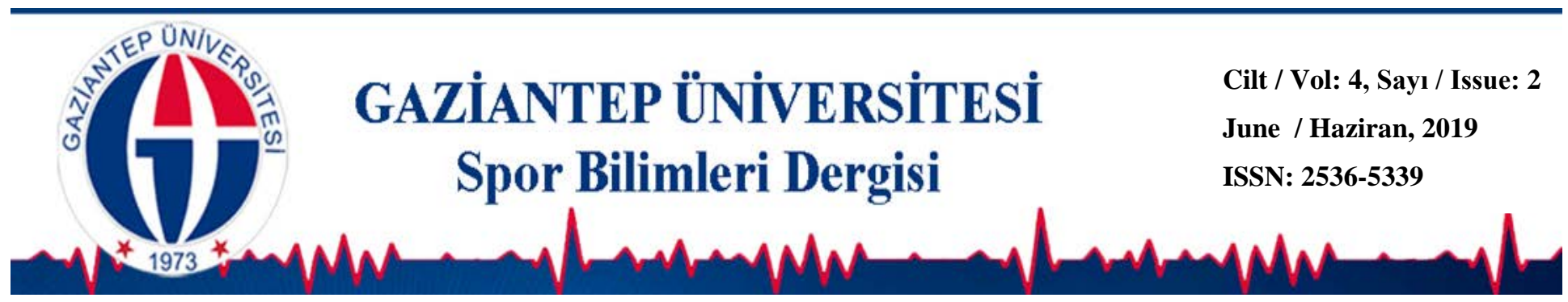

\title{
Sağlıklı Beslenmeye İlişkin Tutum Ölçeği (SBiTÖ): Geçerlik ve Güvenirlik \\ Çalışması
}

\author{
Gönül TEKKURŞUN DEMIR ${ }^{1 *}$ iD \\ ${ }^{1}$ Gazi Üniversitesi, Spor Bilimleri Fakültesi, ANKARA
}

Halil İbrahim CicioĞLU ${ }^{1} \mathbb{D}$

DOI: $10.31680 / g a u n j s s .559462$

Orijinal Makale / Original Article

Geliş Tarihi / Received: 30.04.2019～Kabul Tarihi / Accepted: 30.05.2019ＹＩayın Tarihi / Published: 28.06.2019

\section{Öz}

Bu araştırmada sağlıklı beslenmeye ilişkin tutum ölçeğinin geçerli ve güvenilir olarak geliştirimesi amaçlanmıştır. Araştırma, 2018-2019 eğitim-öğretim yılında öğrenim gören 573 üniversite öğrencisi üzerinde yürütülmüştür. Açımlayıcı Faktör Analizi sonucunda, toplam varyansın \% 57,79'unu açıklayan, 21 madde ve 4 faktörden oluşan bir yapı elde edilmiştir. Bu faktörler, Beslenme Hakkında Bilgi (BHB), Beslenmeye Yönelik Duygu (BYD), Olumlu Beslenme $(\mathrm{OB})$ ve Kötü Beslenme (KB) olarak adlandırılmıştır. Doğrulayıcı faktör analizi sonucunda ölçeğin yeterli uyum indekslerine sahip olduğu kanıtlanmıştır. Ölçeğin güvenirliği iç tutarlılık katsayısı ve test tekrar test yöntemiyle incelenmiş, hesaplanan güvenirlik katsayılarının kabul edilebilir sınırlar içerisinde yer aldığı belirlenmiştir. Madde analizi sonucunda ölçekte yer alan maddelerin tamamının ayırt edici olduğu ortaya koyulmuştur. Sonuç olarak, Sağlıklı Beslenmeye İlişkin Tutum Ölçeği (SBiTÖ)'nin geçerli ve güvenilir bir ölçme aracı olduğu saptanmıştır.

Anahtar Kelimeler: beslenme, sağlıklı beslenme, beslenmeye ilişkin tutum, tutum, ölçek geliştirme

\section{Attitude Scale for Healthy Nutrition (ASHN): Validity and Reliability Study}

\begin{abstract}
In this study, it was aimed to develop a valid and reliable attitude scale for healthy nutrition. The research was conducted on 573 university students studying in the academic year 2018-2019. As a result of Exploratory Factor Analysis, a structure consisting of 21 items and 4 factors explaining $57.79 \%$ of the total variance was obtained. These factors are referred to as Information on Nutrition (IN), Emotion for Nutrition (EN), Positive Nutrition (PN) and Malnutrition (MP). As a result of confirmatory factor analysis, it was proven that the scale have adequate fit indices. The reliability of the scale was analyzed by internal consistency coefficient and test-retest method. It was determined that the calculated reliability coefficients were within acceptable limits. As a result of the item analysis, it was revealed that all items included in the scale were distinctive. As a result, it was determined that Attitude Scale for Healthy Nutrition (ASHN) was a valid and reliable measurement tool.
\end{abstract}

Keywords: nutrition, healthy nutrition, attitude for nutrition, attitude, scale development

\footnotetext{
* Sorumlu Yazar: Gönül TEKKURŞUN DEMİR
}

E-mail: gonultekkursun@hotmail.com 


\section{Giriş}

Dünya sağlık politikalarının temel amacı sağlıklı kişilerin oluşturduğu sağlıklı topluma ulaşmaktır. Bu politikalar kapsamında sunulan sağlık hizmetleri sağlıklı toplumun oluşmasını tek başına sağlayamaz. Her bir bireyin sağlıklı yaşam sürmesi için, gerekli olan fiziksel aktivite, spor, sağlıklı beslenme gibi davranış kalıplarını yaşam ritüeli haline getirmesi gerekmektedir.

Beslenme, insanın, büyümesi, gelişmesi, sağlıklı ve üretken olarak uzun yaşam sürmesi için gerekli olan besinleri yeterli düzeyde alıp vücutta kullanılmasıdır (Müftüoğlu, 2003). Sağlıklı beslenme; bireyin yaşı, cinsiyeti ve fizyolojik durumu göz önünde bulundurularak ihtiyacı olan tüm besin öğelerinin yeterli miktarda karşılanması (Baysal, 1997), yağda düşük, lif açısından yüksek ve meyve ve sebze tüketiminde yüksek bir diyet olarak tanımlanmaktadır (Conner vd., 2002). Sağlıklı beslenme; tüketilen besinden keyif alarak, çeşitli ve dengeli beslenerek, bütün besin ögelerinin bireye özel gereksinim duyulan miktarda yenilmesi ve ideal vücut ağırlığının devam ettirilmesidir. Sağlıklı beslenmenin hedefi; yeterli ve dengeli beslenmenin sağlanmasıdır (Besler ve Rakıcıoğlu, 2015). Öğrencilerin genel olarak ana öğünlerine dikkat etmedikleri, yalnızca tek öğün yemek yedikleri, tost ve simit gibi gıdaları daha çok tükettikleri, maddi zorlukların, yeterli olmayan ve dengesiz beslenme sorunlarında etkili olduğu, yurtta kalan öğrencilerin yurt koşullarının kötü olmasından kaynaklı beslenmelerinin iyi düzeyde olmadığı, yalnızca karınlarını doyurdukları tespit edilmiştir (Durmaz ve ark., 2002; Garibağaoğlu ve ark., 2006; Heşeminia ve ark., 2002). Oysa, sağlıklı beslenmek için günde harcanan enerjinin \%45-60'ının karbonhidratlardan, \%25-35'inin yağlardan ve \%10-20'sinin ise proteinlerden sağlanması gerekmektedir (TC Sağlık Bakanlığı Türkiye Beslenme Rehberi, 2015). Fakat üniversite öğrencilerinin ailelerinden farklı şehirlerde yaşaması, özgür olma isteği ile aile tavsiyelerine direnme, ekonomik problemler, ana öğünleri atlama, karın doyurmanın beslenme olarak algılanması, zayıf görünümün güzel görünme ile eşanlamlı olarak algılanmasından kaynaklanan sağlıksız beslenme tutumları sergileyebilmektedirler.

Tutum, bir bireye atfedilen ve onun psikolojik bir kavram ile ilgili düşünce, duygu ve davranışlarını oluşturan bir eğilim şeklinde tanımlanmaktadır (Kağıtçıbaşı, 2004). Tutum, obje, fikir ve gruplara yönelik kabul ya da ret meylimizi, bu obje, fikir, grupların lehinde veya aleyhinde hislerimizi gösterir (Gay ve Airasian, 2000). Tutum 
genel olarak bireyin dışında kalan çevresinde herhangi bir durum ya da nesneye verdiği tepki yönelimini ifade eder. Diğer bir ifade ile tutum, bireyin bir olgu, vaka ya da durum karşısında ortaya koyması beklenen olası davranış biçimi olarak ifade edilebilir (İnceoğlu, 2010). Tutum kavramı sosyal psikologlarca kabul edilmiş ve bir bireyi gözlemleyerek bir olguya ilişkin tutumun ne yönde olduğuna ilişkin fikir sahibi olabilir (Tavşancıl, 2014). Alanyazında tutumların ortaya çıkışı, kaynağı, tutumun kişilerin hareketlerine etkisi ve tutumların belli zaman içinde değişiklik göstermesi bilim dünyasının her zaman ilgisini çekmiş olmakla birlikte çok miktarda araştırmaya konu olmuştur (Tekkurşun Demir ve ark, 2017). Tutum ruhsal hal ve çevre dünyanın oryantasyonunu oluşturmakla birlikte konu hakkındaki bilgi düzeyi, duygusal yaklaşım ve tavırların iç içe geçmiş halidir. Buna göre bir bireyin tutumu; olgu, vaka ya da duruma yönelik sahip olduğu bilgi (bilişsel), o duruma olumlu-olumsuz duyguları (duygusal) ve konu ile ilgili çeşitli söylemleri ve eylemleri (davranışsal) ile ortaya çıkar.

Literatürde sağlıklı beslenmeye yönelik yapılan çeşitli araştırmalara (Altıncı ve ark., 2016; Bassett, Beagan ve Chapman, 2008; Condon, Crepinsek ve Fox, 2009; Ergin, Şen ve Erbay, 2007; Güleç, Yabancı, Göçgeldi ve Bakır, 2008; İlhan, Batmaz ve Akhan, 2010; Özme, Çetinkaya, Saygın, vd, 2011; Vançelik, Önal, Güraksın ve Beyhun, 2007; Yılmaz ve Özkan, 2007) rastlanmasına rağmen sağlıkı beslenmeye yönelik tutumları ölçen bir ölçme aracına rastlanmamıştır. Bu bağlamda araştırmada sağlıklı beslenme tutumlarının geçerli ve güvenilir olarak ölçülmesi için Sağlıklı Beslenmeye İlişkin Tutum Ölçeği'nin geliştirilmesi amaçlanmıştır.

\section{Yöntem}

\section{Araştırmanın Modeli}

Araştırmada karma model kullanılmıştır. Karma model, araştırma boyunca nitel ve nicel modelin bir arada kullanımını içeren bir yaklaşımdır (Creswell ve Plano Clark, 2007). Creswell'e (2008) göre karma model çalışmalarının ana varsayımı, nitel ve nicel araştırma modelinin birlikte yada harmanlanarak iç içe kullanılmasının araştırma problem ve sorularının bu modelin ayrı kullanılmasından daha iyi ortaya konmasını sağlamaktadır. 


\section{Çalışma Grubu}

Araştırmaya ilk olarak 18 (7 kadın, 11 erkek) üniversite öğrencisi dahil edilmiş ve onlara günlük sağlıklı ve sağlıksız beslenmeye ilişkin (ölçekte kullanılacak ters maddeler için) görüşleri alınmıştır. Daha sonra araştırmaya madde havuzunun anlaşırlığını test etmek için 41 üniversite öğrencisi dahil edilmiştir. Ardından araştırmaya 2017-2018 Eğitim-Öğretim yılında Ankara ili Gazi Üniversitesi'nde öğrenim gören Beden Eğitimi Öğretmenliği Bölümü’nden 50 (15 kadın, 35 erkek), Bankacılık Sigortacılık Bölümü'nden 45 (32 kadın, 13 erkek), Siyaset Bilimi Bölümü'nden 51 (17 kadın, 34 erkek), Hukuk Fakültesi'nden 50 (26 kadın, 24 erkek), İstatistik Bölümü'nden 50 (22 kadın, 18erkek), Maliye Bölümü'nden 40 (22 kadın, 18 erkek), Kimya Mühendisliği Bölümü'nden 50 (31 kadın, 19 erkek), Bankacılık Bölümü'nden 47 (18 kadın, 29 erkek), Konservatuar Bölümü'nden 43 (16 kadın, 27 erkek) ve PDR Bölümü'nden 50 (10 kadın, 40 erkek) olmak üzere toplam 476 üniversite öğrencisi katılmıştır. Son olarak test tekrar test ve DFA analizleri için araştırmaya Beden Eğitimi Öğretmenliği Bölümü'nden 38 (17 kadın, 21 erkek) ve PDR Bölümü'nden 20 (12 kadın, 8 erkek) olmak üzere 58 öğrenci katılmıştır. Bu bağlamda araştırmaya toplam 573 üniversite öğrencisi katılmıştır. Literatürde çalışma grubunun, geliştirilen ölçek madde sayısının beş katı kadar olması gerektiğine dair görüşler yer almaktadır (Balcı, 2005; Büyüköztürk, Kılıç-Çakmak, Akgün, Karadeniz ve Demirel, 2012; Pett, Lackey ve Sullivan, 2003; Tavşancıl, 2014; Tezbaşaran, 2008). Bu bağlamda çalışma grubunun oldukça yeterli sayıda olduğu söylenebilir.

\section{SBITÖ'nün Geliştirilme Süreci}

Öncelikle ölçekte kullanılacak olan "tutum" özelliği ve "tutum alt boyutları" ile ilgili alanyazın taranmıştır. Çünkü ölçek geliştirme çalışmalarında ilk olarak ölçülmek istenen özelliğin kuramsal yapısı ve kuram doğrultusunda özelliğin alt boyutlarının araştırılması gerekmektedir (De Vellis, 2014). Bu bağlamda tutum özelliğinin kuramı, tanımı, alt boyutları (bilişsel, duyuşsal ve davranışsal) tanımlanmış ve alanyazındaki tutum ölçekleri (Demirhan ve Altay, 2001; Erkuş ve ark., 2000; Güllü ve Güçlü, 2009; Görgüt ve Güllü, 2017; Hazar ve Demir, 2018; Koçak, 2014; Soyer ve ark., 2016; Şentürk, 2015; Tekkurşun Demir ve Mutlu Bozkurt, 2019; Üstüner, 2006) ile tutuma yönelik yapılan araştırmalar (Tekkurşun Demir ve ark., 2017; Kaya ve ark., 2018; 
Tekkurşun Demir, G., Cicioğlu, Hİ., (2019). Sağlıklı Beslenmeye İlişkin Tutum Ölçeği (SBİTÖ): Geçerlik ve Güvenirlik Çalışması. Gaziantep Üniversitesi Spor Bilimleri Dergisi, 4(2), 256-274.

Kalfa, 2019; Kırımoğlu ve ark., 2017; Kııımoğlu ve ark., 2016; Yıldız ve ark., 2017) taranmıştır.

Literatür taramasının ardından araştırmaya gönüllü olarak katılan 18 (7 kadın, 11 erkek) üniversite öğrencisi ile yüz yüze görüşmeler (nitel görüşme) yapılmıştır. Öğrencilere uzman görüşü doğrultusunda hazırlanan açık uçlu görüşme formlarında yer alan sorular yöneltilmiştir. Bu bağlamda katılımcılara sağlıklı ve sağlıksız beslenmeye ilişkin (ölçekte kullanılacak ters maddeler için) sorular sorulmuştur. Böylece katılımcıların sağlıklı beslenmeye ilişkin duygu ve düşünceleri tespit edilmiştir. Katılımcılardan elde edilen görüşler tekrara düştüğü için katıımcı sayısı 18 kişi ile sınırlandırımıştır.

Açık uçlu sorulara alınan cevaplar, tutum özelliğinin kuramsal yapısı ve alanyazında geliştirilmiş olan tutum ölçekleri dikkate alınarak mevcut ölçeğin madde havuzu oluşturulmuştur. Yetersiz, anlatım bozukluğu içeren, anlaşılmayan, özelliği temsil etmeyen maddelerin çıkarılacağı düşünüldüğü için madde havuzu için oluşturulan maddeler mümkün olduğunca fazla tutulmuştur. Bu bağlamda oluşturulan ilk madde havuzunda bilişsel, duyuşsal ve davranışsal boyutu temsil ettiği düşünülen 93 madde yer almaktadır. Nitekim Tavşancıl (2014)'a göre, ölçek geliştirilirken oluşturulan madde sayısının 100 civarında olması gerekir. Buna göre madde havuzu yeterli sayıdadır.

Madde havuzunda yer alan her bir maddenin yanına uygun, uygun değil, düzeltilmeli kutucukları oluşturularak madde havuzu uzman görüşüne sunulmuştur. Uzman görüşü alınmasındaki amaç kapsam geçerliliğinin sağlanmasıdır. Kapsam geçerliliği ölçekteki her bir maddenin ölçülmek istenen tutum özelliğine uygun olup olmadığının "uzman görüşüyle" ortaya konmasıdır (Karasar, 2014; Tekin, 2004). Kapsam geçerliliği için her uzman madde havuzundaki maddeleri, ifadenin anlaşır olması, dilin yalın-uygun olması ve özelliği karşılaması açısından değerlendirmiştir. Bu bağlamda madde havuzu Beden Eğitimi ve Spor Öğretmenliği alanından dört, Ölçme ve Değerlendirme alanından iki, Türk Dili ve Edebiyatı alanından bir, Beslenme ve Diyetetik Bölümünden üç öğretim üyesine sunulmuştur. Uzman görüşü doğrultusunda 93 maddelik madde havuzu 50 madde şeklinde düzenlenmiş ve taslak ölçek olarak uygulamaya hazır hale getirilmiştir. Çalışma grubuna uygulamadan önce taslak ölçek 5'li likert tipinde hazırlanmıştır. Bu bağlamda katıımcılardan sağlıklı beslenmeye yönelik tutumlarını beş kategoride değerlendirmeleri istenmiştir. 
Tekkurşun Demir, G., Cicioğlu, Hİ., (2019). Sağlıklı Beslenmeye İlişkin Tutum Ölçeği (SBİTÖ): Geçerlik ve Güvenirlik Çalışması. Gaziantep Üniversitesi Spor Bilimleri Dergisi, 4(2), 256-274.

Ölçekteki olumlu maddelere ait derecelendirme "Kesinlikle Katılmıyorum", "Katımıyorum", "Kararsızım", "Katıııyorum", “Kesinlikle Katılıorum" şeklindedir. Olumlu tutum maddeleri; 1, 2, 3, 4 ve 5 olumsuz tutum maddeleri ise 5, 4, 3, 2 ve 1 şeklinde puanlanmıştır.

Taslak ölçek, çalışıması planlanan çalışma grubu ile benzer özelliklere sahip 41 üniversite öğrencisine uygulanmış, taslak ölçeğin anlaşılırlığı ve yeterliliği test edilmiştir. Bu uygulama sonrasında katııımılarda aynı anlamı taşımayan 2 madde analiz dışı bırakılarak 48 maddelik taslak ölçeğe son hali verilmiştir.

48 maddelik taslak ölçek 476 üniversite öğrencisini içeren çalışma grubuna uygulanmış ve ölçeğin nihai formuna ulaşmak amacıyla bir dizi geçerlik güvenirlik çalışmasına tabi tutulduktan sonra 21 maddelik nihai ölçek formuna ulaşılmıştır. Nihai ölçeğe ulaşmak üzere yapılan analizler, bulgular bölümde yer almaktadır.

\section{Bulgular}

\section{Yapı Geçerliliği}

Bu çalışmada, SBiTÖ'nün yapı geçerliğini incelemek amacıyla Açımlayıcı Faktör Analizi ve Doğrulayıcı Faktör Analizi uygulanmıştır.

\section{Açımlayıcı Faktör Analizi (AFA)}

Sağlıklı Beslenmeye Illişkin Tutum Ölçeği'nin yapı geçerliği ve güvenirlik çalışmaları için 476 kişilik çalışma grubundan veri toplanmıştır. Bu uygulama sonucunda elde edilen verilere AFA uygulanmıştır. AFA yapılırken öncelikle KaiserMayer-Olkin (KMO) ve Barlett testi yapılmıştır. Örneklem uygunluğu 0,87; Bartlett Sphericity testi ki-kare değeri ise, 5076,914 ( $s d=476 ; p=0,001)$ olarak bulunmuştur. $\mathrm{Bu}$ değerin 0,05'ten küçük değerde olması korelasyon matrisindeki faktörlerden birinin çalışma dışı bırakılabileceğini göstermektedir (Şencan, 2005). Büyüköztürk'e (2010) göre, KMO değerinin ,60'dan yüksek olmasıyla birlikte Barlett testinin de anlamlılık göstermesi verilerin faktör analizi için uygun koşulları sağladığının kanıtı olarak kabul edilmektedir. Tavşancıl (2002)'a göre, KMO değeri 1'e yaklaştıkça mükemmel, 0,80'lerde çok iyidir. Ardından Maksimum Likelihood yöntemi doğrultusunda faktör analizi yapılmıştır. Rotasyon, ölçeğin ortaya çıkabilecek olan faktörlerinin ilişki içinde olduğu kabul edilerek, eğik döndürme yönteminden (direct oblimin) yararlanılmıştır. Ölçeğin faktörleşmesinde öz değeri 1 'in üzerinde olan 
faktörler anlamlı kabul edilerek araştırmaya alınmış ve Scree Plottan yararlanılmıştır. SBITÖ'nün her bir faktör yükünün incelenmesinde en az ,40 değeri kritik değer olarak alınmıştır. AFA sonucunda öz değeri 1' in üzerinde olan ve toplam varyansın yaklaşık \% 57,79'unu açıklayan 4 faktörlü bir faktör matrisi ortaya çıkmıştır. Literatürde maddelerin birden fazla faktöre yük verdiği analizlerde, iki faktörde yer alan bu maddelerin faktör yük değerleri arasında 0,10'dan az fark olması durumunda maddelerin analiz dışı bırakılması gerektiği yer almaktadır (Büyüköztürk, 2006; Bütüner ve Gür, 2007; Tavşancıl, 2005; Yavuz, 2005). Bu bağlamda AFA'da bu kriterlere uymayan 5., 6., 7., 8., 9., 10., 11., 12., 13., 14., 15., 16., 17., 18., 19., 20., 22., 24., 25., 27., 29., 30., 31., 32., 33., 37., 48. madde olmak üzere toplam 27 madde analiz dışı bırakıımıştır. Scree Plot incelendiğinde (bkz. Şekil 1) dört faktörlü yapıyı gösterdiği belirlenmiştir ve analiz sonucu Tablo 1'de sunulmuştur.

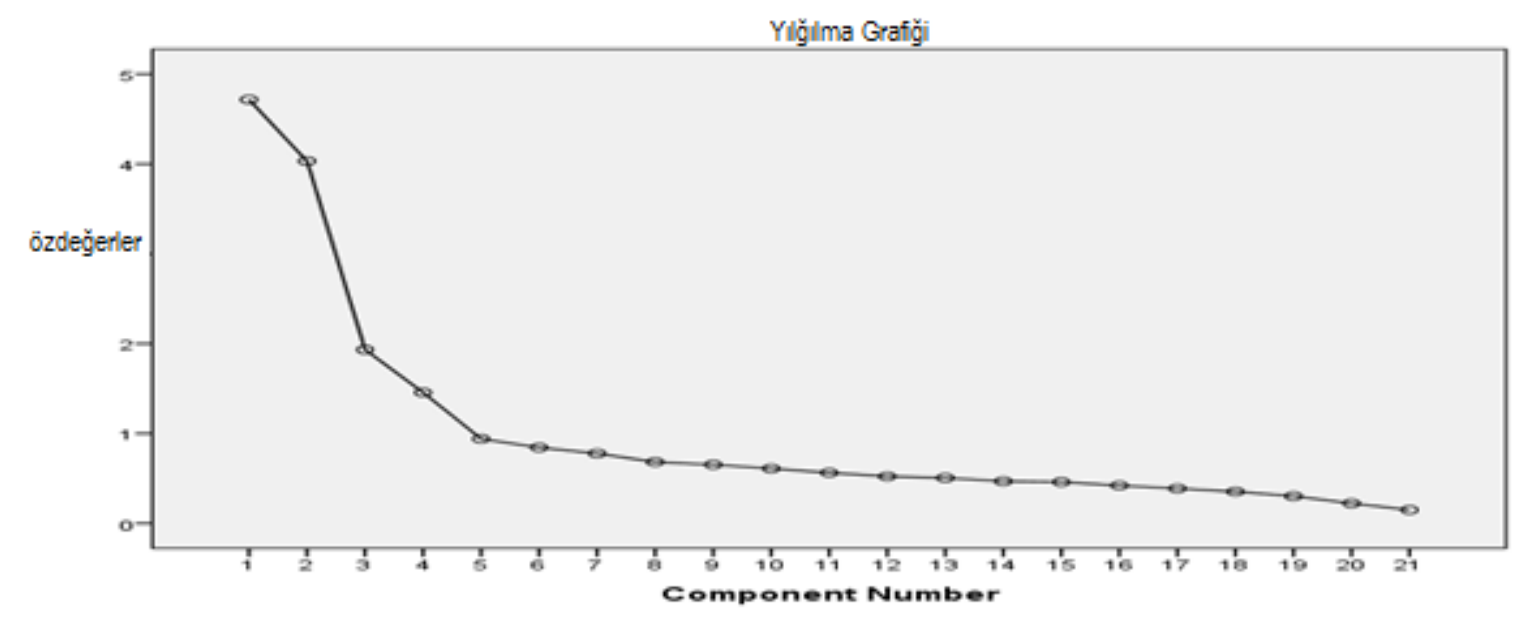

Şekil 1. AFA sonucu Scree Plot

Şekil 1'de AFA sonucuna göre elde edilen Scree Plot incelendiğinde 4 faktörlü yapıyı gösterdiği saptanmıştır. 
Tablo 1. SBiTÖ'nün AFA Sonuçları

\begin{tabular}{|c|c|c|c|c|c|}
\hline $\begin{array}{l}\frac{0}{C} \\
\frac{0}{0} \\
\frac{0}{0} \\
\frac{\pi}{2}\end{array}$ & & 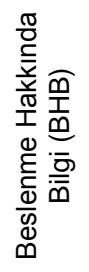 & 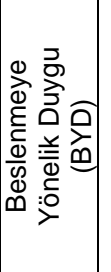 & 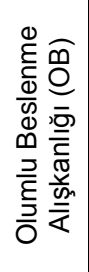 & 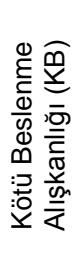 \\
\hline 1 & Sağlıklı beslenmenin yararlarını bilirim. & 95 & & & \\
\hline 2 & Hangi besinlerin protein içerdiğini bilirim. & 91 & & & \\
\hline 3 & Hangi besinlerin karbonhidrat içerdiğini bilirim. & ,86 & & & \\
\hline 4 & Hangi besinlerin vitamin/mineral içerdiğini bilirim. & 61 & & & \\
\hline 5 & Sağlıklı besinlerin neler olduğunu bilirim. & ,56 & & & \\
\hline 6 & Şekerli besinleri (çikolata, pasta, vb.) yediğimde mutlu olurum.* & & 75 & & \\
\hline 7 & Fastfood ürünleri (hamburger, pizza vb.) yemekten keyif alırım. ${ }^{*}$ & & 69 & & \\
\hline 8 & Şarküteri ürünleri (sosis, sucuk, vb.) yemekten zevk alırım. * & & ,66 & & \\
\hline 9 & Yağda kızarmış besinlerin yemeyi severim*. & & ,64 & & \\
\hline 10 & Meyve tüketmekten hoşlanmam.* & & ,61 & & \\
\hline 11 & Şerbetli tatıları (baklava, künefe vb.) tükettiğimde mutlu olurum.* & & ,41 & & \\
\hline 12 & Ana öğünleri (kahvaltı-öğle ve akşam yemeği) düzenli yerim. & & & 65 & \\
\hline 13 & Günde en az 1,5 It su içerim. & & & ,63 & \\
\hline 14 & Haftada en az 3 öğün sebze tüketirim. & & &, 57 & \\
\hline 15 & Düzenli meyve tüketirim. & & &, 53 & \\
\hline 16 & Her gün protein içeren besinleri (et, süt, yumurta, vb.) yerim. & & &, 46 & \\
\hline 17 & Ana öğünleri atlarım.* & & & & ,69 \\
\hline 18 & Her gün abur cubur (cips, bisküvi, vb.) yerim.* & & & & ,65 \\
\hline 19 & Her gün asitli/gazlı içeceklerden en az 1 bardak içerim. * & & & & ,64 \\
\hline 20 & Ayaküstü beslenirim. * & & & & ,64 \\
\hline 21 & Ana öğünümü genellikle kek, bisküvi gibi gıdalarla geçiştiririm.* & & & & ,59 \\
\hline
\end{tabular}

AFA sonuçları incelendiğinde, SBITÖ'nün yapı geçerliliği sonuçlarına göre 21 maddeli 4 faktörlü yapı elde edilmiştir. Ölçme aracında faktör yükü ,40’tan düşük maddenin olmadığı, ölçek maddelerinin faktör yüklerinin ,41 ve ,95 arasında değiştiği görülmektedir. Büyüköztürk (2010) ve Seçer (2015) AFA'da faktör yüklerinin en az ,30 olmasını önermektedir. Faktörlerde toplanan maddelerin içerikleri ve kuramsal yapı dikkate alınarak birinci faktör Beslenme Hakkında Bilgi (BHB), ikinci faktör Beslenmeye Yönelik Duygu (BYD), üçüncü faktör Olumlu Beslenme (OB) ve dördüncü faktör Kötü Beslenme (KB) olarak adlandırılmıştır. Özdeğeri 4,73 olan BHB faktörü 6 maddeden oluşmakta ve toplam varyansın \% 22,45'ini açıklamaktadır. Özdeğeri 4,03 olan BYD faktörü 6 maddeden oluşmakta ve toplam varyansın \% 19,19'unu oluşmaktadır. OB faktörünün özdeğeri 1,93 ve 5 maddeden oluşup toplam varyansın \% 9,71'ini açıklamaktadır. Özdeğeri 1,45 olan KB faktörü 5 maddeden oluşmakta ve toplam varyansın \% 6,93'ünü açıklamaktadır. 


\section{Doğrulayıcı Faktör Analizi (DFA)}

AFA sonucunda elde edilen 21 madde ve dört faktörden oluşan yapının uyum indekslerini tespit etmek ve SBITÖ'nün AFA'da elde edilen 4 faktörlü yapının uygunluğunu saptamak için DFA uygulanmıştır. Uyum indekslerine ilişkin dikkate alınması gereken aralıklar tartışmalı bir konu (Weston ve Gore, 2006) olsa da literatürde kabul edilebilir ve iyi varsayılan ölçütlere yönelik değer aralıkları Tablo 2' de verilmiştir (Alpar, 2013; Çerezci, 2010; Çelik ve Yılmaz, 2013; Doğan, 2015; Doğan ve Özdamar, 2017; Kline, 2011; Marsh, Hau, Artelt, Baumert ve Peschar, 2006; Meyers, Gamst ve Guarino, 2006; Meydan ve Şeşen, 2011; Özdamar, 2013; Sümer, 2000; Schermelleh-Engel ve Moosbrugger, 2003; Tabachnick ve Fidell, 2007; Tezcan, 2008; Thompson, 2004).

Tablo 2. Doğrulayıcı Faktör Analizi Sonuçları

\begin{tabular}{lccc}
\hline $\begin{array}{l}\text { Model } \\
\text { İndeksleri }\end{array}$ & $\begin{array}{c}\text { Sağlıklı Beslenmeye } \\
\text { Ilişkin Tutum Ölçeği }\end{array}$ & İyi Varsayılan Aralık & Kabul Edilebilir Aralık \\
\hline $\mathrm{X}^{2} / \mathrm{sd}$ & 1,71 & $0<\mathrm{x}^{2} / \mathrm{sd}<2$ & $2<\mathrm{x}^{2} / \mathrm{sd}<3$ \\
$\mathrm{RMSEA}$ & 0,04 & $0.00<\mathrm{RMSEA}<0.05$ & $0.05 \leq \mathrm{RMSEA} \leq 0.10$ \\
$\mathrm{PGFI}$ & 0,74 & $0.95 \leq \mathrm{PGFI} \leq 1.00$ & $0.50 \leq \mathrm{PGFI} 0.95$ \\
$\mathrm{PNFI}$ & 0,82 & $0.95 \leq \mathrm{PNFI} \leq 1.00$ & $0.50 \leq \mathrm{PNFI} 0.95$ \\
$\mathrm{GFI}$ & 0,92 & $0.95 \leq \mathrm{GFI} \leq 1.00$ & $0.90 \leq \mathrm{GFI}<0.95$ \\
$\mathrm{AGFI}$ & 0,90 & $0.90 \leq \mathrm{AGFI} \leq 1.00$ & $0.85 \leq \mathrm{AGFI}<0.90$ \\
$\mathrm{IFI}$ & 0,98 & $0.95 \leq \mathrm{IFI} \leq 1.00$ & $0.90 \leq \mathrm{IFI}<0.95$ \\
$\mathrm{NFI}$ & 0,95 & $0.95 \leq \mathrm{NFI} \leq 1.00$ & $0.90 \leq \mathrm{NFI}<0.95$ \\
$\mathrm{CFI}$ & 0,98 & $0.97 \leq \mathrm{CFI} \leq 1.00$ & $0.95 \leq \mathrm{CFI}<0.97$ \\
\hline
\end{tabular}

Sağlıklı Beslenmeye Illişkin Tutum Ölçeği' nin doğrulayıcı faktör analizi sonuçlarında; elde edilen uyum indeksi değerleri, $x^{2} / s d=1,71$, RMSEA $=0,04$, PGFI=0,74, PNFI=0,82, GFI=0,92, AGFI=0,90, $I F I=0,98, \quad N F I=0,95$ ve $C F I=0,98$ olarak bulunmuştur. Buna göre, DFA ile sınanan modelin yeterliğini ortaya koymak amacıyla incelenen uyum indekslerinin yeterli endekslerine sahip olduğu görülmektedir. Bu bağlamda Şekil 2'de SBiTÖ'ye ilişkin Path Diyagramı yer almaktadır. 


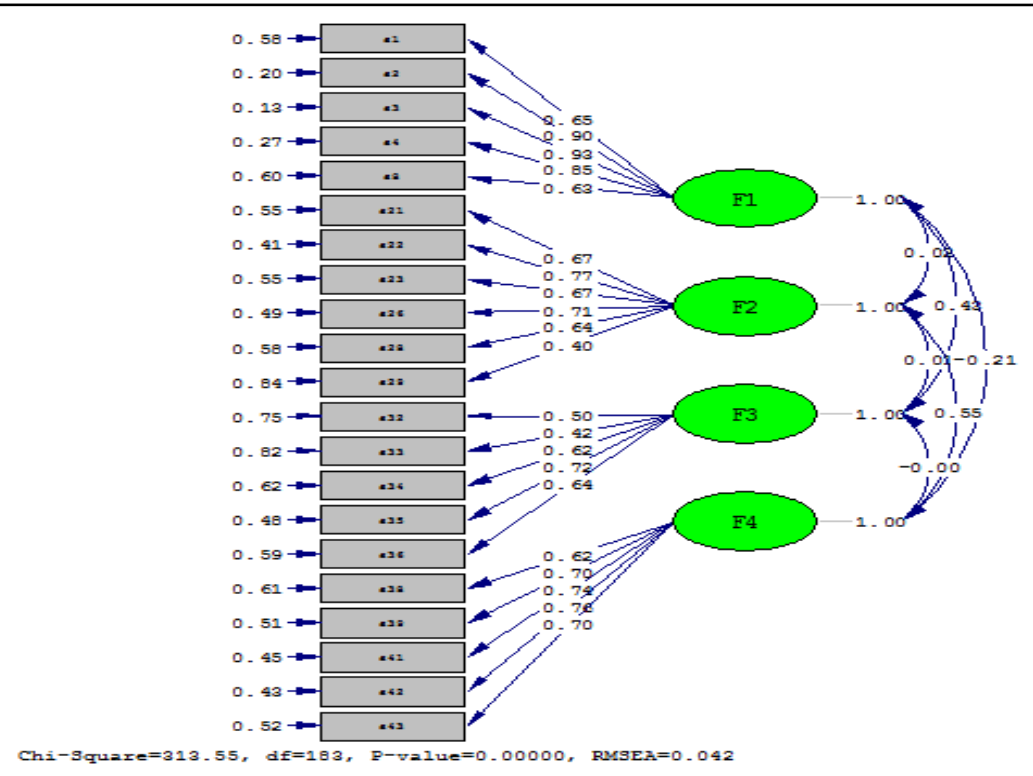

Şekil 2. SBiTÖ’ye ilişkin Path Diyagramı

SBiTÖ'ye ilişkin Path Diyagramı (Şekil 2), DFA'da elde edilen uyum endekslerine kanıt olarak gösterilebilir. Şekil 2'de F1= Beslenme Hakkında Bilgi (BHB), F2= Beslenmeye Yönelik Duygu (BHB), F3= Olumlu Beslenme (OB), F4= Kötü Beslenme (KB) faktörlerini temsil etmektedir.

\section{Güvenirlik}

SBiTÖ'nün güvenirliği, iç tutarlılık ve test tekrar test yöntemleri ile hesaplanmışıı. Araştırmada 476 öğrenciden elde edilen veriler üzerinden hesaplanan iç tutarlıık katsayıları, Beslenme Hakkında Bilgi (BHB) faktörü için ,90 Beslenmeye Yönelik Duygu (BHB) faktörü için ,84, Olumlu Beslenme (OB) faktörü için ,75 ve Kötü Beslenme (KB) faktörü için ,83 olarak bulunmuştur. Uzmanlara göre iç tutarlık katsayısı 0,80 ile 1 arasında ise ölçek yüksek güvenirliliğe sahiptir (Alpar, 2001; Büyüköztürk, 2014; Tavşancıl, 2014). Güvenirlik katsayısına ilişkin bu ölçütlere göre, SBiTÖ'nün faktörleri için iç tutarııık katsayılarının yeterli sınırlarda yer aldığı söylenebilir. Ölçeğin zamana karşı değişmezliğini ortaya koymak amacıyla benzer örneklem grubuna $(n=58)$ iki hafta ara ile ölçek uygulanmıştır. Uygulama sonunda elde edilen test tekrar test güvenirlik katsayısı sırasıyla ,81;, $79 ;, 68$ ve 80 olarak hesaplanmıştır. Bu değerlerin ,70'ten yüksek olduğu dikkate alındında test tekrar test güvenirlik katsayılarının da yeterli sınırlar içerisinde yer aldığı söylenebilir. 


\section{Madde Analizi}

Birden çok faktörlü olan ölçeklerde, alt-üst grupların modeli oluşturan faktörleri için tanımlanması ve o faktörde yer alan madde puanlarının karşılaştırılması gerekmekterdir (Büyüköztürk, 2014). Bu nedenle, SBiTÖ’deki maddelerin madde ayırt edicilik düzeylerini saptamak ve toplam puanı yordama gücünü tespit etmek amacıyla düzeltilmiş madde toplam korelasyonu hesaplanmış ve toplam ölçek puanına göre hesaplanmış \% 27'lik üst ve \% 27'lik alt grubun ortalama puanları arasındaki karşılaştırmalara yer verilmiştir. Madde toplam korelasyonun hesaplanmasında Pearson Momentler Çarpımı Korelasyonu kullanılmıştır. \%27'lik alt üst grup karşılaştırmalarında ise Bağımsız örneklemler için $t$ testinden yararlanılmıştır. Madde analizi sonucunda elde edilen bulgular Tablo 3'te sunulmuştur.

Tablo 3. SBITÖ’nün Madde Analizi Sonuçları

\begin{tabular}{|c|c|c|c|c|c|c|c|c|}
\hline \multirow[t]{2}{*}{$\begin{array}{l}\text { Madde } \\
\text { No }\end{array}$} & \multirow{2}{*}{$\begin{array}{l}\text { Madde } \\
\text { Toplam } \\
\text { Korelasyonu }\end{array}$} & \multirow[t]{2}{*}{ Faktörler } & \multicolumn{2}{|c|}{$\begin{array}{l}\text { Üst \% } 27 \\
\text { Grup n= } 129\end{array}$} & \multicolumn{2}{|c|}{$\begin{array}{l}\text { Alt \% } 27 \\
\text { Grup n=129 }\end{array}$} & \multirow[t]{2}{*}{$\mathrm{t}$} & \multirow[t]{2}{*}{$\mathrm{p}$} \\
\hline & & & $X$ & SS & $\mathrm{x}$ & SS & & \\
\hline 1. & ,92(*) & \multirow{5}{*}{ BHB } & 4,34 & ,83 & 3,59 & 1,20 & 5,75 & ,00* \\
\hline 2. & ,91 (*) & & 4,36 & ,85 & 3,20 & 1,20 & 8,88 & ,00* \\
\hline 3. & ,90(*) & & 4,32 & ,85 & 3,37 & 1,15 & 7,50 & ,00* \\
\hline 4. & ,79(*) & & 4,32 & ,88 & 3,45 & 1,13 & 6,83 & ,00* \\
\hline 5. & ,76(*) & & 4,44 & ,80 & 3,79 & 1,11 & 5,39 & ,00* \\
\hline 6. & ,79(*) & \multirow{6}{*}{ BYD } & 4,36 & ,81 & 3,02 & 1,32 & 9,77 & ,00* \\
\hline 7. & ,78(*) & & 4,37 & ,78 & 2,77 & 1,17 & 12,91 &, $00 *$ \\
\hline 8. & ,78(*) & & 4,31 & ,91 & 2,87 & 1,28 & 10,35 &, $00^{*}$ \\
\hline 9. & ,75(*) & & 4,29 & ,87 & 2,79 & 1,15 & 11,80 & ,00* \\
\hline 10. & ,72(*) & & 4,30 & ,83 & 3,07 & 1,22 & 9,39 &, $00^{*}$ \\
\hline 11. & ,68(*) & & 4,21 & 1,06 & 3,09 & 1,42 & 7,16 & ,00* \\
\hline 12. & ,82(*) & \multirow{6}{*}{ OB } & 3,77 & 1,10 & 2,87 & 1,28 & 6,01 &, $00^{*}$ \\
\hline 13. & ,80(*) & & 4,17 & ,96 & 3,39 & 1,37 & 5,24 & ,00* \\
\hline 14. & ,80(*) & & 3,94 & 1,22 & 2,77 & 1,35 & 7,26 & ,00* \\
\hline 15. & ,78(*) & & 4,10 & ,98 & 2,87 & 1,26 & 8,69 & ,00* \\
\hline 16. &, $75\left(^{*}\right)$ & & 4,20 & ,84 & 3,11 & 1,22 & 8,35 & ,00* \\
\hline 17. & ,77(*) & & 3,58 & 1,33 & 2,30 & 1,10 & 8,43 &, $00^{*}$ \\
\hline 18. & ,76(*) & \multirow{4}{*}{ KB } & 3,74 & 1,22 & 2,06 & 1,18 & 11,20 & ,00* \\
\hline 19. & ,71(*) & & 3,54 & 1,38 & 1,96 & 1,23 & 9,67 & ,00* \\
\hline 20. &, $70\left(^{*}\right)$ & & 3,80 & 1,15 & 2,22 & 1,23 & 10,61 & ,00* \\
\hline 21. &, $69(*)$ & & 3,90 & 1,14 & 2,44 & 1,23 & 9,85 &, $00^{*}$ \\
\hline
\end{tabular}

Ölçekte, \% 27'lik üst ve alt gruplar arasındaki toplam puan farkına yönelik olarak anlamlı farklılık tespit edilmiştir. Üst ve alt grup arasında yapılan analizlerdeki farkın anlamlı düzeyde olması maddenin ayırt ediciliği için bir kanıttır (Erkuş, 2014). 
Tablo 3'e göre, analizler sonunda madde toplam korelasyonuna ait değerlerin ,68 ile ,92 arasında yer aldığı saptanmıştır. Tüm bu analizler doğrultusunda, SBiTÖ'yü oluşturan maddelerin ölçekle ilişki düzeyinin tatmin edici nitelikte olduğu ve bu maddelerin ölçekle uyumlu olduğu görülmüştür.

\section{Tartışma ve Sonuç}

Sağlıklı beslenmeye ilişkin tutumu ölçen geçerli ve güvenilir bir ölçme aracının geliştirilmesinin amaçlandığı bu araştırmaya 2018-2019 eğitim-öğretim yılında Ankara ili Gazi Üniversitesi'nde Beden Eğitimi Öğretmenliği, Bankacılık Sigortacılık, Siyaset Bilimi, Hukuk, İstatistik, Maliye, Kimya Mühendisliği, Bankacılık, Konservatuar ve PDR Bölümlerinde öğrenim gören toplam 476 üniversite öğrencisi katılmıştır.

Katılımcılardan toplanan verilerin AFA'ya uygunluğunun tespiti için yapılan Kaiser-Mayer-Olkin (KMO) testi sonucu 0,87; Bartlett Sphericity testi ki-kare değeri ise, 5076,914 $(\mathrm{sd}=476 ; \mathrm{p}=, 000)$ olarak saptanmıştır. Verilerin faktör analizine uygunluğu tespit edildikten sonra Maksimum Likelihood yöntemi kullanılarak faktör analizi yapılmıştır. Tutumun, düşünce, duygu ve davranışları içeren üç faktölü bir yapısı olduğu (Kağıtçıbaşı, 2004) bilinmektedir, fakat AFA sonucunda ölçeğin 21 maddeli dört faktörlü bir yapıya sahip olduğu tespit edilmiştir. Bu faktörler, Beslenme Hakkında Bilgi (BHB), Beslenmeye Yönelik Duygu (BYD), Olumlu Beslenme (OB) ve Kötü Beslenme (KB) olarak adlandırılmıştır. Özdeğeri 4,73 olan BHB faktörü 6 maddeden oluşmakta ve toplam varyansın \% 22,45'ini açıklamaktadır. Özdeğeri 4,03 olan BYD faktörü 6 maddeden oluşmakta ve toplam varyansın \% 19,19'unu oluşmaktadır. OB faktörünün özdeğeri 1,93 ve 5 maddeden oluşup toplam varyansın \% 9,20'sini açıklamaktadır. Özdeğeri 1,48 olan KB faktörü 5 maddeden oluşmakta ve toplam varyansın \% 6,93'ünü açıklamaktadır. Ölçek toplam varyansın \% 57,79'unu açıklamaktadır. Ölçme aracında yer alan faktörlerin, faktör yüklerinin ,40’tan yüksek olduğu, ölçekteki her bir maddenin faktör yüklerinin ,41 ve ,95 arasında değiştiği saptanmıştır. Daha sonra ölçeğin dört faktörlü yapısı DFA sonucunda doğrulanmıştır. Bu bağlamda DFA sonucunda ölçeğin yeterli uyum indekslerine sahip olduğu görülmüştür. Sağlıklı Beslenmeye Iliş̧in Tutum Ölçeği' nin doğrulayıcı faktör analizi sonuçlarında; elde edilen uyum indeksi değerleri, $x^{2} / s d=1,71$, RMSEA $=0,04$, PGFI $=0,74, \mathrm{PNFI}=0,82, \mathrm{GFI}=0,92, \mathrm{AGFI}=0,90, \quad \mathrm{IFI}=0,98, \mathrm{NFI}=0,95$ ve $\mathrm{CFI}=0,98$ şeklindedir. Doğrulayıcı faktör analizinin uygunluğu kanıtlandıktan sonra ölçeğin 
güvenirliği iç tutarlılık katsayısı ve test tekrar test yöntemiyle incelenmiştir. Buna göre iç tutarlılık katsayıları, Beslenme Hakkında Bilgi (BHB) faktörü için ,90 Beslenmeye Yönelik Duygu faktörü (BYD) için ,84, Olumlu Beslenme (OB) faktörü için ,75 ve Kötü Beslenme (KB) faktörü için ,83 olarak bulunmuştur. Test tekrar test için yapılan uygulama sonunda elde edilen güvenirlik katsayısı sırasıyla ,81; ,79; ,68 ve 80 olarak hesaplanmıştır. Madde analizi sonucunda herhangi bir madde ölçekten çıkarılmamış ve ölçekte yer alan maddelerin tamamının ayırt edici olduğunu ortaya koymuştur. Ayrıca madde toplam korelasyonu değerlerinin ,68 ile ,92 arasında değiştiği saptanmıştır.

Tüm bu analizler ışığında, SBITÖ’nün üniversite öğrencilerinin sağlıklı beslenmeye ilişkin tutumlarını ölçmek amacıyla kullanılabilecek geçerli ve güvenilir bir ölçme aracı olduğu sonucuna varılmıştır. SBiTÖ'den alınabilecek en düşük puan 21, en yüksek puan 105'dur. SBiTÖ'den katılımcıların alacağı 21 puan çok düşük, 23-42 puan düşük, 43-63 puan orta, 64-84 puan yüksek ve 85-110 puan ideal düzeyde yüksek sağlıklı beslenmeye ilişkin tutuma sahip olduğu şeklinde açıklanır.

\section{Kaynaklar}

Altıncı, E. E., Keskin, B., Türksoy, A., Güvendi, B., ve Doğan, G. (2016). İstanbul İli Bayrampaşa Uluğbey İlköğretim Okulu 7 ve 8. Sınıf Öğrencilerinde Beslenme Davranışları ve Obezite Durumlarına Spor Aktivitelerinin Etkisi. İstanbul Üniversitesi Spor Bilimleri Dergisi, 6(4), 17-27.

Alpar, R. (2000). Spor Bilimlerinde Uygulamalı İstatistik. GSGM Yayınları. Ankara. Alpar, R. (2013). Uygulamalı Çok Değişkenli İstatistiksel Yöntemler. Detay Yayıncılık. Balcı, A. (2005). Sosyal Bilimlerde Araştırma Yöntem, Teknik ve İlkeler (5. Baskı). Ankara: PegemYayınları. Başbakanlık Özürlüler İdaresi Başkanlığı (2004). Başbakanlık Devlet İstatistik Enstitüsü Başkanlığı, Devlet İstatistik Enstitüsü Başkanlığı Matbaası. "Eğitim Durumu”, Türkiye Özürlüler Araştırması, Ankara.

Bassett, R., Beagan, B., ve Chapman, G. E. (2008). Grocery lists: connecting family, household and grocery store. British Food Journal, 110(2), 206-217.

Baysal A. (1997). Beslenme. 7.bs.. Ankara: Hatipoğlu Yayınevi:9-18.

Bütüner, Ö. S. ve Gür, H. (2007). V diyagramına yönelik bir tutum ölçeğinin geliştirilme çalışması, Milli Eğitim Dergisi, 176, 72-85. 
Besler, H. T., ve Rakıcıŏlu, N. (2015). Türkiye'ye Özgü Besin ve Beslenme Rehberi. Ankara: Merdiven Reklam Tanıtım. the International Olympic Committee and the International Society for Sports Nutrition. South African journal of clinical nutrition, 26(1), 6-16.

Büyüköztürk, Ş. (2006). Sosyal Bilimler İçin Veri Analizi El Kitabı. İstatistik, Araştırma Deseni SPSS Uygulamaları ve Yorum (6. baskı). Ankara: Pegem A Yayıncılık. Büyüköztürk, Ş. (2010). Sosyal bilimler için veri analizi el kitabı. Ankara: Pegem Akademi Yayınları.

Büyüköztürk, Ş., Kılıç-Çakmak, E., Akgün, Ö. E., Karadeniz, Ş., ve Demirel, F. (2012). Bilimsel Araştırma Yöntemleri (Geliştirilmiş 11.Baskı). Ankara: Pegem Yayınları.

Büyüköztürk, Ş. (2014). Sosyal Bilimler İçin Veri Analizi El Kitabı: İstatistik, Araştırma Deseni SPSS Uygulamaları ve Yorum (Genişletilmiş 20. Baskı). Ankara: Pegem Akademi.

Creswell, J. W. (2008). Educational research planning, conducting and evaluating quantitative and qualitative research. International Pearson Merril Prentice Hall.

Creswell, J., ve Plano Clark, V. L. (2007). Understanding mixed methods research. In J. Creswell (Ed.), Designing and conducting mixed methods research (pp. 1-19). Thousand Oaks, CA: Sage.

Conner, M., Norman, P., ve Bell, R. (2002). The theory of planned behavior and healthy eating. Health psychology, 21(2), 194.

Condon E., M., Crepinsek, M., K., ve Fox, M., K. (2009). School Meals: Types of foods offered to and consumed by children at lunch and breakfast. J Am Diet Assoc; 109: 67-78.

Çelik, H. E., ve Yılmaz, V. (2013). Lisrel 9.1 Ille Yapısal Eşitlik Modellemesi: Temel Kavramlar Uygulamalar-Programlama (Yenilenmiş 2.Baskı). Ankara: Anı Yayıncılık.

Çerezci, T. E. (2010). Yapısal Eşitlik Modelleri ve Kullanılan Uyum İyiliği İndekslerinin Karşılaştırılması, Doktora Tezi, Gazi Üniversitesi Fen Bilimleri Enstitüsü, Ankara.

Demirhan, G., ve Altay, F. (2001). Lise Birinci Sınıf Öğrencilerinin Beden Eğitimi Ve Spora İlişkin Tutum Ölçeği Iı. Spor Bilimleri Dergisi, 12(2), 9-20. 
De Vellis, R. F. (2014). Ölçek Geliştirme: Kuram Ve Uygulamalar (Ed.Tarık Totan). Ankara: Nobel Yayıncılık.

Doğan, İ. (2015). Farklı Veri Yapısı ve Örneklem Büyüklüklerinde Yapısal Eşitlik Modellerinin Geçerliği Ve Güvenirliğinin Değerlendirilmesi. Eskişehir Osmangazi Üniversitesi Sağlık Bilimleri Enstitüsü, Eskişehir.

Doğan, İ., ve Özdamar, K. (2017). The Effect Of Different Data Structures, Sample Sizes On Model Fit Measures. Communications İn Statistics-Simulation And Computation, 46(9), 7525-7533.

Durmaz, Ş., Kaçar, Z., Can, S., Koca, R. ve Yeşilova, D. (2007). Çanakkale Sağlık Yüksekokulu Öğrencilerinin Problem Çözme Becerileri ve Etkileyen Bazı Faktörler. Atatürk Üniversitesi Hemşirelik Yüksekokulu Dergisi, 10 (4), 63-71.

Erkuş, A. (2014). Psikolojide Ölçme ve Ölçek Geliştirme-l: Temel Kavramlar Ve İşlemler (2. Baskı). Ankara: Pegem Yayınları.

Erkuş, A., Sanlı, N., Bağlı, M. T., ve Güven, K. (2000). Öğretmenliğe ilişkin tutum ölçeği geliştirilmesi. Eğitim ve Bilim, 25(116).

Garibağaoğlu, M., Budak, N., Öner, N., Sağlam, Ö. ve Nişli, K. (2006). Üç farklı üniversitede eğitim gören kız öğrencilerin beslenme durumları ve vücut ağırlıklarının değerlendirmesi, Sağlık Bilimleri Dergisi, 15(3), 173-180.

Gay, L. R., ve Airasian, P. (2000). Educational Research. New Jersey: Upper Saddle River.

Güleç, M., Yabancı, N., Göçgeldi, E., ve Bakır, B. (2008). Ankara'da iki kız öğrenci yurdunda kalan öğrencilerin beslenme alışkanlıkları. Gülhane Tıp Dergisi, 50(2), 102-109.

Güllü, M., ve Güçlü, M. (2009). Ortaöğretim Öğrencileri İçin Beden Eğitimi Dersi Tutum Ölçeği Geliştirilmesi. Beden Egitimi Ve Spor Bilimleri Dergisi, 3(2).

Görgüt, İ., ve Güllü, M. (2017). Ortaokul Öğrencileri İçin Hentbol Tutum Ölçeği Geliştirilmesi. Journal Of Physical Education \& Sports Science/Beden Egitimi Ve Spor Bilimleri Dergisi, 11(1).

Hazar, Z., ve Demir, G. T. (2018). Attitude scale towards Game and Physical Activities course of class teacher candidates: Validity and reliability study Sınıf öğretmeni adaylarının Oyun ve Fiziksel Etkinlikler dersine yönelik tutum ölçeği: Geçerlik ve güvenirlik çalışması. Journal of Human Sciences, 15(2), 12061215. 
Tekkurşun Demir, G., Cicioğlu, Hİ., (2019). Sağlıklı Beslenmeye İlişkin Tutum Ölçeği (SBİTÖ): Geçerlik ve Güvenirlik Çalışması. Gaziantep Üniversitesi Spor Bilimleri Dergisi, 4(2), 256-274.

Heşeminia, T., Çalışkan, D., ve Işık, A. (2002). Ankara'da yüksek öğretim öğrenci yurtlarında kalan öğrencilerin beslenme sorunları. İbni Sina Tıp Dergisi 7: 155166

Illhan E. L., Esentürk O. K., ve Yarımkaya E. (2016). Attitude scale of individuals having mental disabilities towards sports activities zebseytö Validity and reliability study, Zihinsel engelli bireylerin sportif etkinliklerine yönelik tutum ölçegi zebseytö Geçerlik ve güvenirlik çalısması. International Journal of Human Sciences, 13(1), 1141-1160., Doi:10.14687/ijhs.v13i1.3656

İlhan, N., Batmaz, M., ve Akhan, L. U. (2010). Üniversite öğrencilerinin sağlıklı yaşam biçimi davranışları. Maltepe Üniversitesi Hemşirelik Bilim ve Sanatı Dergisi, 3(3), 34-44.

İnceoğlu, M. (2010). Tutum Algı İletişim, Beykent Üniversitesi Yayınları No: 69, 5. Baskı, İstanbul.

Kalfa, M. (2019). Diş Hekimliği Fakültesindeki Öğrencilerinin Spora Yönelik Tutumları. Spormetre Beden Eğitimi Ve Spor Bilimleri Dergisi, 17(1), 165-181.

Karasar, N. (2014), Bilimsel Araştırma Yöntemleri: Kavramlar, Teknikler Ve İlkeler (27. Baskı). Ankara: Nobel Yayınevi.

Kağıtçıbaşı, Ç. (2004). İnsan ve İnsanlar, Psikolojiye Giriş, Gözden Geçirilmiş Onuncu Baskı, Evrim Basım-Yayım-Dağııım, İstanbul.

Kaya, Ö., Cicicoğlu, H. İ., ve Demir, G. T. (2018). The Attitudes Of University Students Towards Sports: Attitude And Metaphorical Perception. European Journal of Physical Education and Sport Science, 5 (1), 115-133.

Kırımoğlu, H., Yılmaz, A., ve Kaynak, K. (2016). An evaluation of pre-and in-service preschool teachers' attitudes towards sports activities of individuals with intellectual disabilities: Kocaeli province example. British Journal of Education, Society \& Behavioural Science, 16 (3), 1, 9.

Kırımoğlu, H., Dallı, M., Yıımaz, A., ve Say, M. (2017). Öğretmen Adaylarının Zihinsel Engelli Bireylerin Sportif Etkinliklerine Yönelik Tutum Düzeylerinin İncelenmesi (Muğla Sıtkı Koçman Üniversitesi Örneği). Journal of Human Sciences, 14(4), 3116-3125.

Koçak, F. (2014). Üniversite öğrencilerinin spora yönelik tutumları: bir ölçek geliştirme çalışması. SPORMETRE Beden Eğitimi ve Spor Bilimleri Dergisi, 12(1), 59-69. 
Kline, R. B. (2011). Principles and practice of structural equation modeling. New York: The Guilford Press.

Meydan, H.C., ve Şeşen, H. (2011). Yapısal eşitlik modellemesi AMOS uygulamaları. Ankara: Detay Yayıncılık.

Meyers, L.S, Gamst, G., ve Guarino, A.J. (2006). Applied multivariate research: Design and Interpretation. London: SAGE Publications.

Marsh, H. W., Hau, K.T., Artelt, C., Baumert, J., ve Peschar, J.L. (2006). OECD's brief self-report measure of educational psychology's most useful affective constructs: Cross-cultural, psychometric comparisons across 25 countries. International Journal of Testing, 6(4), 311-360.

Müftüoğlu O. (2003). Yaşasın Hayat. Doğan Kitapçılık AŞ, İstanbul, 32-87.

Özdamar, K. (2013). Paket programlar ile istatistiksel veri analizi-Cilt 1, 9. baskı. Ankara: Nisan Kitabevi

Özmen, D., Çetinkaya, A. Ç., Ergin, D., Şen, N. ve Erbay P.,D. (2007). Lise öğrencilerinin yeme alışkanlıkları ve beden ağırlığını denetleme davranışları. Kor Hek; 6: 98-105.

Pett, M., Lackey, N., ve Sullivan, J. (2003). Making Sense Of Factor Analysis. Thousand Oaks: SagePublications, Inc.

Saygın, M., Öngel, K., Çalışkan, S., Yağlı, M., Has, M., Gonca, T., ve Kurt, Y. (2011). Süleyman Demirel Üniversitesi öğrencilerinin beslenme alışkanlıkları. SD Ü Tıp Fakültesi Dergisi, 18(2), 43-47.

Seçer, İ. (2015). SPSS Ve Lisrel İle Pratik Veri Analizi: Analiz ve Raporlaştırma. Ankara: Anı Yayıncılık.

Soyer, F., Sentürk, U., Koyuncuoglu, K., ve Yilmaz, A. (2016). Attitude Scale Toward Game Lesson of the Class Teachers. The Anthropologist, 25(1-2), 141-150.

Sümer, N. (2000). Yapısal Eşitlik Modelleri. İstanbul: Türk Psikoloji Yayınları Schermelleh-Engel, K., ve Moosbrugger, H. (2003). Evaluating The Fit Of Structural Equation Models: Tests Of Significance And Descriptive Goodness Of Fit Measurement. Methods of Psychological Research Online, 8(2), 23-74.

Şentürk, H. E. (2015). Sportif Tutum Ölçeği: Geliştirilmesi, Geçerliliği Ve Güvenirliği. Cbü Beden Eğitimi Ve Spor Bilimleri Dergisi, 7(2), 8-18.

Şencan, H. (2005). Sosyal ve Davranışsal Ölçümlerde Geçerlilik ve Güvenirlik, Seçkin Matbaası, Ankara. 
Tabachnick, B. G., ve Fidell, L. S. (2007). Using multivariate statistics (5th ed.). New York: Allyn and Bacon.

Tavşancıl, E. (2002), Tutumların ölçülmesi ve spss ile veri analizi, Ankara: Nobel Yayıncılık.

Tavşancıl, E. (2005). Tutumların ölçülmesi ve SPSS ile veri analizi. Ankara: Nobel Yayıncılık.

Tavşancıl, E. (2014).Tutumların Ölçülmesi ve SPSS İle Veri Analizi (5. Baskı). Ankara: Nobel Yayınevi.

Tekin, H. (2004). Eğitimde Ölçme ve Değerlendirme. (Onyedinci Baskı). Ankara: Yargı Yayınevi.

Tezcan, C. (2008). Yapısal Eşitlik Modelleri, Yüksek Lisans Tezi, Hacettepe Üniversitesi Fen Bilimleri Enstitüsü, Ankara

Tezbaşaran, A. A. (2008). Likert Tipi Ölçek Geliştirme Kılavuzu (3. baskı). Ankara: Türk Psikologları Derneği Yayınları.

Tekkurşun Demir, G., Cicioğlu, H. İ, İlhan, E, L ve Arslan, Ö. (2017). Sınıf Öğretmeni Adaylarının Beden Eğitimi Dersine Yönelik Tutumları. International Journal of Sport, Exercise \& Training Sciences - ljsets, 3(4), 120-128. Doı: 10.18826/Useeabd.319676.

Tekkurşun Demir, G. ve Mutlu Bozkurt, T. (2019). Dijital Oyun Oynama Tutumu Ölçeği (DOOTÖ): Geçerlik Ve Güvenirlik Çalışması, Sportif Bakış: Spor ve Eğitim Bilimleri Dergisi, 6(1), 1-18.

TC Sağlık Bakanlığı Türkiye Beslenme Rehberi -TÜBER- (2015). Sağlık Bakanlığı Yayınları, Ankara.

Thompson, B. (2004). Exploratory And Confirmatory Factor Analysis: Understanding Concepts And Applications. Washington, DC, US: American Psychological Association.

Üstüner, M. (2006). Öğretmenlik mesleğine yönelik tutum ölçeğinin geçerlik ve güvenirlik çalışması. Kuram ve Uygulamada Eğitim Yönetimi Dergisi, 12(1), 109-127.

Weston, R., ve Gore, P.A. (2006). A brief guide to structural equation modeling. The Counseling Psychologist, 34(5), 719-751. 
Tekkurşun Demir, G., Cicioğlu, Hİ., (2019). Sağlıklı Beslenmeye İlişkin Tutum Ölçeği (SBİTÖ): Geçerlik ve Güvenirlik Çalışması. Gaziantep Üniversitesi Spor Bilimleri Dergisi, 4(2), 256-274.

Vançelik, S., Önal, S. G., Güraksın, A., ve Beyhun, E. (2007). Üniversite öğrencilerinin beslenme bilgi ve alışkanlıkları ile ilişkili faktörler. TSK Koruyucu Hekimlik Bülteni, 6(4), 242-248.

Yavuz, S. (2005), Developing a technology attitude scale for pre-service chemistry teachers, The Turkish Online Journal of Educational Technology, 4(1).

Yılmaz, E., ve Özkan, S. (2007). Üniversite öğrencilerinin beslenme alışkanlıklarııın incelenmesi. Fırat Sağlık Hizmetleri Dergisi, 2(6), 87-104.

Yıldız, A. B., Arı, Ç., ve Yılmaz, B. (2017). Üniversite öğrencilerinin spora yönelik tutumlarının incelenmesi (Ankara Yıldıım Beyazıt Üniversitesi örneği). 